\title{
Pedagogical Content Knowledge (PCK) Mathematics Pre- service Teachers in Developing Content Representations (CoRes)
}

\author{
${ }^{1}$ Suripah, ${ }^{2}$ Suyata, ${ }^{3}$ Heri Retnawati \\ ${ }^{1}$ Universitas Islam Riau, JL. Kaharuddin Nasution No. 113 Perhentian Marpoyan, Pekanbaru, Indonesia \\ 2Universitas Ahmad Dahlan, Jl. Pramuka, Sidikan, Yogyakarta, Indonesia \\ 3Universitas Negeri Yogyakarta, Jl. Colombo, Caturtunggal, Depok, Sleman, Yogyakarta, Indonesia \\ e-mail:rifah@edu.uir.ac.id
}

\begin{abstract}
This study aimed to determine the pedagogical content knowledge (PCK) of pre-service teachers in developing CoRes as a support for designing mathematics learning. Data were collected by reviewing documents of CoRes development results by 32 pre-service teachers' after analyzing school mathematics learning documents in the form of syllabi and lesson plans prepared by experienced teachers. The analysis of the results of the pre-service CoRes document made by the pre-service teachers' is done using descriptive statistics that are by calculating the mean. The results of the data analysis show that $18.8 \%$ of the pre-service teachers achieved very good qualification, $56.3 \%$ with good qualification, $15.6 \%$ with sufficient qualification, and $9.4 \%$ with poor qualification. Although there were still pre-service teachers belonged to the poor qualification, there were no pre-service teachers who failed in developing CoRes. Some individual students still seem to have difficulty developing CoRes. However, the CoRes document that has been prepared is very useful for carrying out further activities. Thus, it can be concluded that the development of CoRes can be used by pre-service teachers as a support to design learning.
\end{abstract}

Keywords: CoRes, learning, PCK, pre-service teacher

How to Cite: Suripah, Suyata, \& Retnawati, H. (2021). Pedagogical Content Knowledge (PCK) Mathematics Pre-service Teachers in Developing Content Representations (CoRes). International Journal on Emerging Mathematics Education, 5(1), 41-50. http://dx.doi.org/10.12928/ijeme.v5i1.19954

\section{INTRODUCTION}

Many mathematics graduates who enroll in the teacher education courses are lacking an understanding of the cognitive aspect required in teaching (Loughran et al., 2008). They do not understand that effective teaching is a skilled and directed activity that involves complex processes of pedagogical reasoning (Shulman, 1987). Besides, pre-service teachers often do not realize that pedagogical reasoning and action are supported by complex basic knowledge that is used by experienced teachers and develops as they take the teaching profession. This observation is supported by the results of research on science teachers that indicate that many science teachers do not have a deep conceptual understanding of science, so their ideas on certain science topics are fragmented and disorganized (Loughran et al., 2008). The other research in the field of mathematics also indicates that teachers have not yet fully invited students to learn how to implement learning procedures (Subanji, 2016). Therefore, preparing an effective generation of teachers, it requires the good preparation of the pre-service teachers (Moore, 2016).

Knowledge of the implementation of learning is part of the initial ability which pre-service teachers must have. Pre-service teachers should know how to teach the 
material and understand their students (Blum et al., 2019). Besides, pre-service teachers must also understand and integrate content knowledge in curriculum, students, and learning (Turnuklu \& Yesildere, 2007). This is due to the direct relationship between teachers and curriculum implementation practices (Retnawati, 2015).

The teacher plays an important role in the context of educating the children. This is evident that the practice of education at schools depends on what their teachers teach (NCTM, 2000). According to Arends (2012), effective teachers can at least understand and build students' commitment as active learners. In line with this, the efforts to produce effectively skilled teachers in teacher training institutions require a process and continuity. Likewise, designing and evaluating learning while carrying out assignments is not an easy thing to do. All of these jobs require lengthy training to create effective learning. Hiebert et al. (2007) added that to produce capable teachers after graduation, teacher training institution needs to prepare prospective student teacher to learn how to teach.

Pre-service teachers take professional education that is prepared to obtain the skills needed in a systematic way. Pre-service teacher education programs aim to prepare quality graduates and meet the increasing need associated with the teaching profession (Hammon, 2010). Pre-service teachers must be motivated to explore personal values professionally (Carr, 2004). Besides, pre-service teachers have the opportunity to continue developing and improving their mathematics ability through the experience gained (Davis \& Krajcik, 2005). It is hoped that pre-service teachers will be able to develop alternative orientations towards mathematics and learning by continuing to improve pedagogical content knowledge. According to Shulman (1987), content and pedagogical knowledge is the main key for learning activities that must be integrated to create new knowledge, namely the Pedagogical Content Knowledge (PCK). Furthermore, Mishra \& Koehler (2006) said that a teacher who has mature Pedagogical Content Knowledge could understand how students build knowledge, acquire skills, develop habits, and internalize positive dispositions towards learning.

However, as a matter of fact, there are many problems that occur in mathematics learning. Mergler and Spooner-Lane (2012) report that pre-service teachers need to increase commitment to continue learning, getting to know, and responding to student diversity. Furthermore, Morris et al. (2009) suggested that pre-service teachers can identify the sub-concepts of mathematics learning goals in a supportive context. Some pre-service teachers have not been able to teach the material correctly (Peker, 2009). Besides, pre-service teachers have not been able to implement learning strategies to plan or evaluate learning (Killen, 2009). This evidence contributes to a negative image for the students about mathematics as a difficult subject (Retnawati et al., 2011).

One effort that can be done to overcome these problems is to prepare preservice teachers by strengthening pedagogical content knowledge. Shulman (1987) proposes several domains to overcome the complexity of knowledge based on the knowledge experienced by the teacher. These categories include content knowledge; curriculum knowledge; pedagogical content knowledge; knowledge of learners and their characteristics. This knowledge is based on the structures, mathematics education research, and the wisdom of practice.

According to constructivist perspectives related to learning, the process of building knowledge is understanding through mental structures, the intellectual development of students. It can be observed through the process of creating new knowledge based on the knowledge that already exists in the previous child (Schunk,

IJEME, Vol. 5, No. 1, March 2021, 41-50. 
2012). This process may involve little change in existing mental structures, while on the other hand individuals may be motivated to change existing structures and build different structures to understand new information. Meanwhile, pre-service teachers certainly bring varied experiences and prior beliefs related to the profession and everything related to teaching. In-depth professional knowledge and abilities of experienced mathematics teachers cannot be obtained quickly. The experience will be gained through evolution and accumulated over time through teaching practice (Nilsson, 2008). Therefore, experienced teachers can help pre-service teachers by building what is needed to become successful teachers in their profession.

One of the methods used to prepare pre-service teachers is to provide PCK debriefing with the development of CoRes and PaP-eRs document as a support for designing mathematics learning. CoRes and PaP-eRs are useful for highlighting and giving examples of some aspects that are material topics. Based on the research of Loughran et al. (2008), a pre-service science teacher is trying to highlight PCK using CoRes and PaP-eRs documents to help students understand the complexity of learning science. CoRes and PaP-eRs documents are also expected to help pre-service teachers to develop a picture of the learning that is integrated on particular topics as well as awareness of mathematical big ideas for good learning. The findings from this study strongly suggest that focusing on PCK using CoRes and PaP-eRs to frame their thinking about the relationship between mathematics and pedagogical content helps preservice teachers to get a view related to better learning. In this regard, this study aims to describe the Pedagogical content knowledge mathematics pre-service teachers in developing CoRes as a support for designing mathematics learning.

\section{RESEARCH METHOD}

\section{Research design and stages}

This research is descriptive qualitative research. The data described is data on the ability of pre-service mathematics teachers at the Universitas Islam Riau in developing CoRes document through mathematics planning program course in the academic year 2018/2019. The place of research was conducted in the mathematics education study program at the Universitas Islam Riau. The time for conducting the research will begin in October 2018 until December 2018.

\section{Participants}

The subjects of this study were 32 students of mathematics education study programs taken randomly from 94 students of the mathematics education study program at the Universitas Islam Riau. The object of this research is the ability of mathematics pre-service teachers to develop CoRes.

\section{Data collection method and instrument}

Data on the ability of students in developing CoRes was collected by reviewing CoRes documents developed by 32 pre-service teachers after analyzing school mathematics learning documents in the form of syllabus and lesson plans prepared by experienced teachers. The instrument used to collect data in this study was in the form of non-test data consisting of 12 aspects of the observed assessment. Observation sheets are marked with checkmarks on the assessment options, according to the circumstances of the research subject in preparing the CoRes document. The assessment given is optional if the aspect assessed is given a score of 1 and if no is given a score of 0 . The assessment is carried out individually, then described based on 
criteria such as Table1. Whereas the analysis of the results of the review is generally done using descriptive statistics, namely by calculating the average.

Table 1. Criteria for the ability of pre-service teachers to develop CoRes

\begin{tabular}{ll}
\hline Score Interval & Criteria. \\
\hline $85-100$ & Very good \\
$70-84.9$ & Good \\
$55-69.9$ & Sufficient \\
$30-54.9$ & Poor \\
$<30$ & Fail \\
\hline
\end{tabular}

\section{Data analysis}

The data were analyzed descriptively qualitatively by calculating the average of each of the observed aspects of 12 aspects and describing them. The percentage of achievement score of pre-service teacher ability in CoRes as a whole is calculated from the average achievement of 12 aspects assessed.

\section{RESULTS AND DISCUSSION}

The ability of pre-service teachers to develop CoRes as a support for designing mathematics learning is obtained based on the level of achievement of the abilities of each individual. Based on the results of data analysis, the percentage of average achievement scores for developing CoRes was 77.6\%. The percentage of the level of achievement of the ability of pre-service teachers in developing CoRes is presented in Table 2.

Table 2. Percentage of the level of achievement of pre-service teacher ability in developing CoRes

\begin{tabular}{lll}
\hline Category & Frequency & Percentage (\%) \\
\hline Very good & 6 & 18.8 \\
Good & 18 & 56.3 \\
Sufficient & 5 & 15.6 \\
Poor & 3 & 9.4 \\
Fail & 0 & 0 \\
\hline
\end{tabular}

Table 2 shows that most pre-service teachers have been able to develop CoRes well. When viewed from the frequency of each category, the number of pre-service teachers who reach the minimum good category is 24 people $(75 \%)$. This shows that for the ability to develop CoRes, pre-service teachers have met the minimum criteria $(75 \%)$ of the good category. The percentage of achievement in each aspect assessed in developing the CoRes of the trigonometric concept is presented in Table 3.

From Table 3, it appears that the lowest percentage of assessment aspect obtained by pre-service teachers in developing CoRes is on statements about other things from this material that pre-service teachers know but are not yet known by students. However, pre-service teachers have been able to mention the ideas/concepts of mathematics with a very good category. Overall, the average percentage for achieving each aspect assessed was $77.6 \%$. Based on established criteria, prospective teachers have met the minimum completeness criteria. 
Table 3. Percentage of achievement in each aspect of assessment in developing CoRes

\begin{tabular}{lc}
\hline \multicolumn{1}{c}{ Assessment Aspects } & $\begin{array}{c}\text { Achievement } \\
(\%)\end{array}$ \\
\hline $\begin{array}{l}\text { Subject Identity } \\
\text { Big ideas/mathematical concept }\end{array}$ & 90.6 \\
$\begin{array}{l}\text { A statement about what I intended the students to learn about } \\
\text { the idea }\end{array}$ & 81.3 \\
$\begin{array}{l}\text { A statement about why is it important for the students to know } \\
\text { this. }\end{array}$ & 84.4 \\
$\begin{array}{l}\text { A statement about what else do you know about this idea (that } \\
\text { you do not intend the students to know yet). }\end{array}$ & 59.4 \\
$\begin{array}{l}\text { A statement about the difficulties/limitations of teaching the } \\
\text { ideas. }\end{array}$ & 62.5 \\
$\begin{array}{l}\text { A statement about knowledge about students' thinking which } \\
\text { influences your teaching of this idea. }\end{array}$ & 71.9 \\
$\begin{array}{l}\text { A statement about other factors that influence your teaching of } \\
\text { this idea. }\end{array}$ & 65.6 \\
$\begin{array}{l}\text { A statement about teaching procedures and particular reasons } \\
\text { for using these to engage with this idea). }\end{array}$ & 71.9 \\
$\begin{array}{l}\text { A statement about specific ways of ascertaining students' } \\
\text { understanding or confusion around this idea (include likely range } \\
\text { of responses). }\end{array}$ & 75 \\
$\begin{array}{l}\text { Punctuality } \\
\text { Neatness }\end{array}$ & \\
Average &
\end{tabular}

CoRes is a PCK representation of pre-service teachers developed by Loughran et al. (2004), which consists of descriptions of specific mathematical content. CoRes contains answers to eight questions covering aspects of the material, students, teaching strategies, and assessment system. In detail, the eight CoRes questions are: (1) What I intended the students to learn about the idea; (2) Why is it important for the students to know this; (3) What else do you know about this idea (that you do not intend the students to know yet; (4) Difficulties/limitations connected with teaching this idea; (5) Knowledge about students thinking which influence your teaching of this idea; (6) Other factors that influence your teaching of this idea; (7) Teaching procedures (and particular reasons for using these to engage with this idea); and (8) Specific ways of ascertaining students understanding or confusion around this idea (include likely range of responses. CoRes provides an overview of how a group of teachers conceptualizes the content of a particular material. In this study, the preservice teacher-developed CoRes for the topic of trigonometry material for high school students.

Analysis of the data in Table 2 shows that most pre-service teachers have been able to develop Cores well. Although there are still pre-service teachers who are in the lacking category, there is no pre-service teacher who has failed in developing Cores. When viewed from the frequency of each category show that $18,8 \%$ pre-service teachers achieved very good qualifications, 56,3\% with good qualifications, $15,7 \%$ with sufficient qualifications, and $9,4 \%$ with poor qualifications. This shows that preservice teachers have met the minimum criteria (75\%) of the good category. 
Therefore, to find out which aspects are not yet mastered by pre-service teachers, an analysis of the percentage of achievement for each aspect is carried out.

Based on the percentage of the ability of pre-service teachers to develop CoRes from Table 3 it appears that of the 12 components described in CoRes, the percentage for lowest assessment aspect obtained by pre-service teachers is on statements about "what else do you know about this idea (that you do not intend the students to know yet)". However, pre-service teachers have been able to mention large mathematical ideas/concepts with very good categories as in the example of CoRes results of one of the pre-service teachers as shown in Figure 1.

\begin{tabular}{|c|c|c|c|c|c|}
\hline \multicolumn{6}{|c|}{$\begin{array}{ll}\text { Subjects } & : \text { Mathematics } \\
\text { Class/Semester } & : \text { X/Odd } \\
\text { Material } & : \text { Trigonometri }\end{array}$} \\
\hline \multirow[t]{2}{*}{ Question } & Big Idea A & Big Idea $\mathbf{B}$ & Big Idea C & Big Idea D & Big Idea $E$ \\
\hline & $\begin{array}{l}\text { Trigonometric } \\
\text { ratios on right } \\
\text { triangles }\end{array}$ & $\begin{array}{l}\text { Generalize trigonometric } \\
\text { ratios for angles in } \\
\text { various quadrants and } \\
\text { related angles. }\end{array}$ & $\begin{array}{l}\text { Comparison of } \\
\text { trigonometry for } \\
\text { special angles of } \\
0^{\circ} \text { and } 90^{\circ}\end{array}$ & $\begin{array}{l}\text { Solve contextual } \\
\text { issues related to } \\
\text { trigonometric } \\
\text { ratios }\end{array}$ & $\begin{array}{l}\text { Solve contex tual problems } \\
\text { related to trigonometric } \\
\text { ratios of angles in various } \\
\text { quadrants and related angles. }\end{array}$ \\
\hline $\begin{array}{l}\text { What I } \\
\text { intend the } \\
\text { students to } \\
\text { leam } \\
\text { about the } \\
\text { idea }\end{array}$ & $\begin{array}{l}\text { Explain the } \\
\text { ratio values of } \\
\text { sine, cosine, } \\
\text { tangent, } \\
\text { cotangent, } \\
\text { secan, and } \\
\text { cosecant, }\end{array}$ & $\begin{array}{l}\text { Determine trigonometric } \\
\text { identity values. } \\
\text { Determine the value of } \\
\text { trigonometric } \\
\text { comparisons in various } \\
\text { quadrant. } \\
\text { Determine trigonometric } \\
\text { comparison values for } \\
\text { related angles. }\end{array}$ & $\begin{array}{l}\text { Find out } \\
\text { trigonometric } \\
\text { ratio values for } \\
\text { angles } 0^{\circ} \\
\text { and } 90^{\circ}\end{array}$ & $\begin{array}{l}\text { Solve contextual } \\
\text { problems related } \\
\text { to sine or cosine } \\
\text { ratios. }\end{array}$ & $\begin{array}{l}\text { Using elevation and } \\
\text { depression angles in problem } \\
\text { solving. }\end{array}$ \\
\hline
\end{tabular}

Figure 1. A sample of a CoRes fragment developed by a pre-service teacher

For other aspects of assessment, pre-service teachers have been able to express despite their spread varies. This is in line with the results of research of Nilsson (2008) that to become a professional teacher requires a lot of time and experience. Likewise, for pre-service teachers in developing CoRes, it is only limited to the content knowledge they have through learning in class (Ball Loewenberg et al., 2008). For example, in the statement "difficulties or limitations connected with teaching this idea" pre-service teachers are largely unable to express ideas completely. Pre-service teachers are still limited to the conventional understanding of problem-solving. They have not revealed the learning relationship associated with problem-solving, using various mathematical methods (Marsigit, 2016). This indicates that there are difficulties or limitations related to teaching or certain materials or topics. But in writing the pre-service teachers are still difficult to express explicitly. It is proven by the statement that most the pre-service teachers have not been able to write statements in detail. An example is seen in the development of Subject 18 CoRes shown in Figure 2.

\begin{tabular}{|l|l|l|l|l|l|}
\hline N0. Question & Big Idea A & Big Idea B & Big Idea C & Big Idea D & Big Idea E \\
\hline $\begin{array}{l}\text { 4. } \\
\text { Difficulties/limitati } \\
\text { ons connected with } \\
\text { teaching this idea }\end{array}$ & $\begin{array}{l}\text { Difficulty } \\
\text { understanding the } \\
\text { concept of right } \\
\text { triangle. }\end{array}$ & $\begin{array}{l}\text { Difficulty in } \\
\text { understanding the } \\
\text { concept of } \\
\text { trigonometric } \\
\text { comparisons at angles } \\
\text { of } 30^{\circ}, 45^{\circ} \text {, and } 60^{\circ} .\end{array}$ & $\begin{array}{l}\text { Lack of } \\
\text { mathematical } \\
\text { understanding } \\
\text { ability in } \\
\text { trigonometric. }\end{array}$ & $\begin{array}{l}\text { Difficulty in } \\
\text { understanding the } \\
\text { concept of related } \\
\text { angles. }\end{array}$ & $\begin{array}{l}\text { Difficulty in } \\
\text { trigonometric } \\
\text { identity. }\end{array}$ \\
\end{tabular}

Figure 2. Subject 18's CoRes

IJEME, Vol. 5, No. 1, March 2021, 41-50. 
Pre-service teachers have been able to write aspects of a statement about specific ways of ascertaining students' understanding or confusion around this idea. Based on data analysis as many as $75 \%$ of pre-service teachers have been able to make statements related to specific ways to ensure understanding of trigonometric material. Pre-service teachers learning to teach mathematics related to trigonometry material in different ways according to student diversity (Franke \& Kazemi, 2001). Diversity of students requires pre-service teachers to learn how to use methods or learning strategies according to learning needs. Some pre-service teachers suggest that a way to find out students' understanding is by group learning. Group learning according to Slavin et al. (2012) can improve student achievement. It also can increase student confidence and interest in learning.

Based on data analysis and exposure that has been described, shows that preservice teachers can already design mathematics learning well. This is supported by the activities carried out by the previous pre-service teacher, namely developing concept analysis, compiling concept maps, and developing CoRes. The process that was carried out during the activity turned out to make it easier for pre-service teachers to design mathematics learning trigonometric concepts. This is Consistent with relevant research studies that the results of the development of Cores can be used to design learning in the classroom (Loughran et al., 2008; Hume \& Berry, 2011). The results of this study indicate that to be able to design good learning, pre-service teachers not only develop Cores but before developing CoRes they can first develop concept analysis and construct concept maps.

Based on the established criteria, classically pre-service teachers have met the minimum completeness criteria, even if viewed from individual completeness it must still be improved. This is because the development of documents in the form of CoRes is a new document for pre-service teachers who are not accustomed to doing. As was the opinion of previous researchers including: (De Jong \& Van Driel, 2004; Mulhall et al., 2003; Loughran et al., 2004; and Rollnick et al., 2008), that studies using CoRes and PaP-eRs documents aim to represent PCK from a variety of variations, ranging from research subjects, pre-service teachers, experienced teachers to professors. Therefore, some individual students still seem to experience difficulties because they are not familiar with the document. However, the CoRes document that has been prepared is very useful for further activities. Thus, it can be concluded that the results of the development of CoRes can be used by pre-service teachers as supporters to design mathematics learning.

\section{CONCLUSION}

Pre-service teachers, in general, can develop CoRes in good qualification (77.3\%). Although there are still pre-service teachers who are in the poor qualification, there are no pre-service teachers who have failed in developing CoRes. Some individual pre-service teachers still seem to experience difficulties. The ability to develop CoRes supports pre-service teachers to design mathematics learning.

\section{ACKNOWLEDGEMENT}

The authors wish to thank the Chancellor of the Universitas Islam Riau and Universitas Negeri Yogyakarta who provided facilities during the study, and LPDP-BUDIDN which provided funding facilities for the duration of the study. 


\section{REFERENCES}

Arends, R. I. (2012). Learning to teach. Mc Graw Hill Companies.

Ball, D. L., Thames, M. H., \& Phelps, G. (2008). Content knowledge for teaching: What makes it special. Journal of teacher education, 59(5), 389-407.

Blum, W., Artigue, M., Mariotti, M. A., Sträßer, R., \& den Heuvel-Panhuizen, V. (2019). European traditions in Didactics of Mathematics (p. 212). Springer Nature.

Carr, D. (2004). Moral values and the arts in environmental education: Towards an ethics of aesthetic appreciation. Journal of philosophy of education, 38(2), 221239.

Davis, E. A., \& Krajcik, J. S. (2005). Designing educative curriculum materials to promote teacher learning. Educational researcher, 34(3), 3-14.

De Jong, O., \& Van Driel, J. (2004). Exploring the development of student teachers' PCK of the multiple meanings of chemistry topics. International Journal of Science and Mathematics Education, 2(4), 477-491.

Franke, M. L., \& Kazemi, E. (2001). Learning to teach mathematics: Developing a focus on students' mathematical thinking. Theory Into Practice, 40(2), 102-109.

Hammon, L. D, et al. (2010). Preparing Principals for a Changing World. Jossey-Bass.

Hiebert, J., Morris, A. K., Berk, D., \& Jansen, A. (2007). Preparing teachers to learn from teaching. Journal of Teacher Education, 58(1), 47-61.

Hume, A., \& Berry, A. (2011). Constructing CoRes-a Strategy for Building PCK in Preservice Science Teacher Education. Research in Science Education, 41(3), 341355.

Killen, R. (2009). Effective teaching strategies (5th ed.). C \&C Offset Printing.

Loughran, J., Mulhall, P., \& Berry, A. (2004). In Search of Pedagogical Content Knowledge in Science: Developing Ways of Articulating and Documenting Professional Practice. Journal of Research in Science Teaching, 41(4), 370-391.

Loughran, J., Mulhall, P., \& Berry, A. (2008). Exploring pedagogical content knowledge in science teacher education. International Journal of Science Education, 30(10), $1301-1320$.

Marsigit, M. (2016). Pembelajaran matematika dalam perspektif kekinian. Math Didactic: Jurnal Pendidikan Matematika, 2(3), 132-141.

Mergler, A. G., \& Spooner-Lane, R. (2012). What pre-service teachers need to know to be effective at values-based education. Australian Journal of Teacher Education, $37(8), 66-81$.

Mishra, P., \& Koehler, M. J. (2006). Technological Pedagogical Content Knowledge: A Framework for Integrating Technology in Teacher Knowledge. Teachers College Record, 108(6), 1017-1054.

Moore, K. D. (2016). Effective instructional strategies: From theory to practice. Journal of Indian Education, 42(1), 140-153.

Morris, A. K., Hiebert, J., \& Spitzer, S. M. (2009). Mathematical for Knowledge Teaching in Planning and Evaluating Instruction: What Can Preservice Teachers Learn? Journal for Research in Mathematics, 40(5), 491-529.

Mulhall, P., Berry, A., \& Loughran, J. (2003). Frameworks for representing science teachers pedagogical content knowledge. Asia Pacific on Science Learning and Teaching, 4(2), 1-25.

NCTM. (2000). Principle and Standards for School Mathematics (Vol. 1). The national Council of Teachers of Mathematics.

Nilsson, P. (2008). Teaching for understanding: The complex nature of pedagogical content knowledge in pre-service education. International Journal of Science

IJEME, Vol. 5, No. 1, March 2021, 41-50. 
Education, 30(10), 1281-1299.

Peker, M. (2009). The use of expanded microteaching for reducing pre-service teachers' teaching anxiety about mathematics. Scientific Research and Essays, $4(9), 872-880$.

Retnawati, H. (2015). Hambatan Guru Matematika Sekolah Menengah Pertama Dalam Menerapkan Kurikulum Baru. Jurnal Cakrawala Pendidikan, 3(3), 390-403.

Retnawati, H., Kartowagiran, B., Hadi, S., \& Hidayati, K. (2011). Identifiction of Student'S Learning Difficulties on Mathematics and Science At Elementary School. Jurnal Kependidikan, 41(2), 162-174.

Rollnick, M., Bennett, J., Rhemtula, M., Dharsey, N., \& Ndlovu, T. (2008). The place of subject matter knowledge in pedagogical content knowledge: A case study of South African teachers teaching the amount of substance and chemical equilibrium. International Journal of Science Education, 30(10), 1365-1387.

Schunk, D. H. (2012). Learning theories an educational perspective (6th ed.). Pearson education Inc.

Shulman, L. S. (1987). Knowledge and teaching: foundations of the new reform. Havard Educational Review, 57(1), 1-22.

Slavin, E., Produk, S., \& Produk, D. (2012). Cooperative learning. Nusa Media.

Subanji. (2016). Peningkatan Pedagogical Content Knowledge Guru Matematika Dan Praktiknya Dalam Pembelajaran Melalui Model Pelatihan Teqip. Jurnal IImu Pendidikan, 21(1), 71-79.

Turnuklu, E., \& Yesildere, S. (2007). The Pedagogical Content Knowledge in Mathematics: Pre-Service Primary Mathematics Teachers' Perspectives in Turkey. Issues in the Undergraduate Mathematics Preparation of School Teachers, 1,1-13. 
This page is intentionally left blank.

IJEME, Vol. 5, No. 1, March 2021, 41-50. 